Afr. J. Trad. CAM (2007) 4 (2): 231 - 239

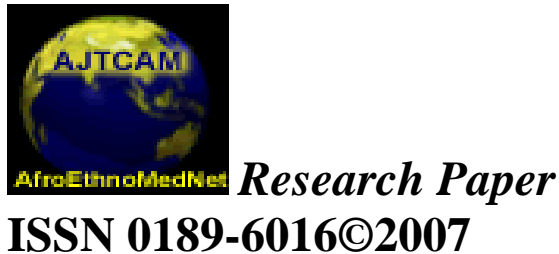

\author{
Afr. J. Traditional, \\ Complementary and \\ Alternative Medicines \\ www.africanethnomedicines.net
}

\title{
SCREENING OF TWENTY-FOUR SOUTH AFRICAN COMBRETUM AND SIX TERMINALIA SPECIES (COMBRETACEAE) FOR ANTIOXIDANT ACTIVITIES.
}

\author{
P. Masoko ${ }^{a b_{*}}$ and J.N. Eloff ${ }^{a}$

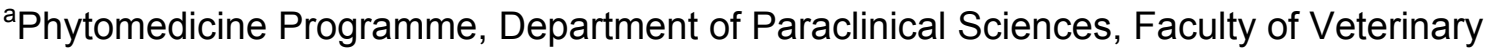 \\ Sciences, University of Pretoria, Private Bag X04, Onderstepoort, 0110, South Africa., \\ ${ }^{b}$ Department of Biochemistry, Microbiology and Biotechnology, Faculty of Health, Sciences \\ and Agriculture, University of Limpopo, Private bag X1106, Sovenga, 0727, South Africa., \\ *E-mail : masokop@ul.ac.za,Tel.: +27 15268 2340; Fax: +27 152683234
}

\begin{abstract}
The dried leaves of Combretum and Terminalia species (Combretaceae) were extracted with acetone, hexane, dichloromethane and methanol. Thin layer chromatography (TLC) plates were developed under saturated conditions and sprayed with $0.2 \%$ 2,2-diphenyl-1-picryl hydrazyl (DPPH) in methanol for antioxidant screening. Visualization of separated bands exhibiting antioxidant activities enabled the localization and the subsequent identification of the potential active compounds. The acetone and methanol extracts displayed the presence of antioxidant activity after spraying the chromatogram with $\mathrm{DPPH}$. Hexane and dichloromethane extracts did not have any antioxidant activity. C. hereroense had the highest number of active compounds, followed by C. collinum ssp. taborense, which were 16 and 10, respectively. Acetone extracts of all tested Combretum species had 53 active bands and methanol had 55. All Terminalia species extracted with acetone and methanol had antioxidant activity. T. gazensis and T. mollis methanol extracts had 11 and 14 active compounds respectively in one of the solvent systems used. The qualitative DPPH assay on TLC was successfully used in this study to systematically assess the total antioxidant activity of the Combretum and Terminalia species extracts.
\end{abstract}

Key words: Combretaceae; Terminalia species; Combretum species; Antioxidant; 2, 2, diphenyl-1picrylhydrazyl (DPPH)

\section{Introduction}

Oxidation in living organisms is essential for the acquirement of energy in catabolism. However, oxygen-centred free radicals and other reactive oxygen species, which are continuously produced in vivo result in cell death and tissue damage. Oxidative damage caused by free radicals may be related to aging, and diseases such as atherosclerosis, diabetes, cancer and cirrhosis (Halliwell and Gutteridge, 1999).

Free radicals are natural by-products of human metabolism. These are charged molecules which attack cells, breaking cellular membranes and reacting with the nucleic acids, proteins, and enzymes present in the cells. These attacks by free radicals, collectively known as oxidative stress, are capable of causing cells to lose their structure, function and eventually result in cell dysfunction. They are continuously produced by our body's use of oxygen, such as in respiration and some cellmediated immune functions. Free radicals are also generated through environmental pollutants, cigarette smoke, automobile exhaust, radiation, air-pollution, pesticides, etc. (Li and Trush, 1994). Normally, there is a balance between the quantity of free radicals generated in the body and the antioxidant defence systems which scavenge/quench these free radicals preventing them from causing deleterious effects in the body (Nose, 2000). The antioxidant defence systems in the body 
Masoko and Eloff. Afr. J. Trad. CAM (2007) 4 (2): 231 - 239

can only protect the body when the quantity of free radicals is within the normal physiological level. But when this balance is shifted towards more free radicals, increasing their burden in the body either due to environmental conditions or infections, it leads to oxidative stress (Finkel and Holbrook, 2000). While the concept of developing drugs from plants used in indigenous medical system is ancient, the link between indigenous use and subsequent scientifically derived biomedical use is not always clear. In some cases the relationship is much more complex (Heinrich and Gibbons, 2001).

Plants (fruits, vegetables, medicinal herbs, etc.) may contain a wide variety of free radical scavenging molecules, such as phenolic compounds (e.g. phenolic acids, flavonoids, quinones, coumarins, lignans, stilbenes, tannins), nitrogen compounds (alkaloids, amines, betalains), vitamins, terpenoids (including carotenoids), and some other endogenous metabolites, which are rich in antioxidant activity (Zheng and Wang, 2001 and Cai et al., 2003). Epidemiological studies have shown that many of these antioxidant compounds possess anti-inflammatory, antiatherosclerotic, antitumor, antimutagenic, anticarcinogenic, antibacterial, or antiviral activities to a greater or lesser extent (Owen et al., 2000; Sala et al., 2002).

Some species from the Combretaceae family have been found to have antioxidant activities in previous studies. Terminalia chebula is used in treatment of fevers, cough, asthma, urinary diseases, piles and worms and is also useful in treating chronic diarrhoea and dysentery, flatulence, vomiting, colic and enlarged spleen and liver (Cheng et al., 2003). Terminalia chebula extracts had different levels of antioxidant activity for anti-LPO, anti-superoxide radical formation and free radical scavenging activities (Cheng et al., 2003). Terminalia arjuna is a large tree distributed throughout India and its bark is used as a cardioprotective agent in hypertension and ischaemic heart diseases. The bark powder is reported to exert hypocholesterolaemic and antioxidant effect in humans (Gupta et al., 2001). Extracts of both Terminalia sericea and Gunnera perpensa showed possible scavenging activity in a concentration dependant manner. Water extracts demonstrated higher activity than the methanol extracts (Mabogo, 1990). Several galloyl quinic acid derivates have been isolated from the galls of Guiera senegalensis (Bouchet et al., 1996) and have shown antioxidant activity (Bouchet et al., 1998).

In 1992, Alexander et al., found several antimicrobial compounds in 12 different Combretum species. Martini and Eloff (1998) found evidence for at least 14 unidentified bacterial inhibitors from the leaves of Combretum erythrophyllum. Eloff (1999) quantified the antibacterial activities of the leaf extracts of 27 members of Combretaceae, and in 2002, Fyhrquist et al. found activity in extracts of the roots and stembark of Combretum and Terminalia species used in Tanzania. The antibacterial properties of Combretum species (Silva et al., 1996 and Baba-Moussa et al., 1998) are well investigated. In our previous studies we have shown that extracts of South African Terminalia species (Masoko et al., 2005) and Combretum species (Masoko et al., 2006) have substantial antifungal activities, with MIC's as low as $20 \mu \mathrm{g} / \mathrm{ml}$.

In previous work, Masoko et al. (2005) indicated that six selected Terminalia species possessed antioxidant activity. Less work has done on Combretum species, except that some compounds isolated from Combretum erythrophyllum possess antioxidant compounds i.e. 5-hydroxy7,4'-dimethoxyflavone but it had the weakest activity (Martini et al., 2004).

Although many synthetic chemicals, such as phenolic compounds, are strong radical scavengers, they usually have side effects (Imaida et al., 1983). Antioxidant substances obtained from natural sources are of great interest. Our main objective was to evaluate the antioxidant activities of various solvent extracts from Combretum and Terminalia species, and to choose a species with promising antioxidant activity for further studies.

\section{Materials and methods Plant collection}

Leaves of Combretum and Terminalia species were collected from plants in the Lowveld National Botanical Garden in Nelspruit, South Africa in the summer of 2003. Voucher specimens and notes on the origins of the trees are kept in the Garden Herbarium. Combretum species collected are listed in Table 1 and Terminalia in Table 2. More information on the origin and voucher reference numbers of these plants are presented elsewhere (Eloff, 1999). 
Masoko and Eloff Afr. J. Trad. CAM (2007) 4 (2): 231 - 239

\section{Plant drying and storage}

Leaves were separated from stems, and dried at room temperature. Most scientists have tended to use dried material because there are fewer problems associated with large scale extraction of dried plants rather than fresh plant material (Eloff, 1998). The dried plants were milled to a fine powder in a Macsalab mill (Model $200 \mathrm{LAB}$ ), Eriez ${ }^{\circledR}$, Bramley, and stored at room temperature in closed containers in the dark until used.

\section{Extraction procedure}

Plant samples from each species were individually extracted by weighing four aliquots of $1 \mathrm{~g}$ of finely ground plant material and extracting with $10 \mathrm{ml}$ of acetone, hexane, dichloromethane (DCM) or methanol (technical grade-Merck), respectively in centrifuge tubes. These tubes were vigorously shaken for 3-5 minutes in a Labotec model 20.2 shaking machine at high speed. After centrifugation at $959 \mathrm{xg}$ for 10 minutes the supernatant was decanted into labelled containers. This process was repeated 3 times to exhaustively extract the plant material and the extracts were combined. The solvent was removed under a stream of air in a fume cupboard at room temperature before dissolving extracts in acetone to a concentration of $10 \mathrm{mg} / \mathrm{ml}$.

\section{Phytochemical analysis}

Chemical constituents of the extracts were analyzed by thin layer chromatography (TLC) using aluminium-backed TLC plates (Merck, silica gel $60 \mathrm{~F}_{254}$ ). The TLC plates were developed with one of the three eluent systems developed in our laboratory which separate components of Combretaceae extracts well i.e.: ethyl acetate/methanol/water (40:5.4:5): [EMW] (polar/neutral); chloroform/ethyl acetate/formic acid (5:4:1): [CEF] (intermediate polarity/acidic); benzene/ethanol/ammonium hydroxide (90:10:1): [BEA] (non-polar/basic) (Kotze and Eloff, 2002). Development of the chromatograms was in a closed tank in which the atmosphere had been saturated with the eluent vapour by lining the tank with filter paper wetted with the eluent.

\section{Antioxidant activity}

Antioxidant activity was determined using qualitative and quantitative analysis namely, the 2 , 2,diphenyl-1-picrylhydrazyl (DPPH) assay and Trolox equivalent antioxidant capacity (TEAC) assay, respectively. In this paper only the qualitative results are given.

\section{Qualitative 2, 2, diphenyl-1-picrylhydrazyl (DPPH) assay on TLC}

TLC was used to separate extracts as described under section 2.4. The plates were dried in the fumehood. To detect antioxidant activity, chromatograms were sprayed with $0.2 \%, 2,2$, diphenyl2-picryl-hydrazyl $\left(\right.$ Sigma $\left.^{\circledR}\right)$ (DPPH) in methanol, as an indicator (Deby and Margotteaux, 1970). The presence of antioxidant compounds was detected by yellow spots against a purple background on TLC plates sprayed with $0.2 \%$ DPPH in methanol.

\section{Results and Discussion}

Various assays have been used to test for antioxidant activity but the mostly widely used methods are those that involve generation of free radical species which are then neutralised by antioxidant compounds (Arnao et al., 2001). In qualitative analysis of antioxidant activity, the 2, 2, diphenyl-1-picrylhydrazyl (DPPH) assay on TLC plates was used as a screening test for the radical scavenging ability of the compounds present in the different extracts.

The DPPH method measures electron-donating activity of other compounds in the mixture and hence provides an evaluation of antioxidant activity due to free radical scavenging. Any molecule that can donate an electron or hydrogen to a mixture will react with and bleach DPPH. DPPH is reduced from a purple compound to a light yellow compound by electrons from oxidant compounds. Reaction of DPPH with hydroxyl groups involves a homolytic substitution of one of the phenyl rings of DPPH yielding 2-(4-hydroxyphenyl)-2-phenyl-1- picryl hydrazine as a major product whilst 2(4nitrophenyl)-2phenyl-1-picrylhydrazine is also formed via a series of secondary processes. The 
Masoko and Eloff Afr. J. Trad. CAM (2007) 4 (2): 231 - 239

Table 1: Combretum species used for antioxidant screening. Infra generic classification from Carr (1988)

\begin{tabular}{|c|c|}
\hline & Combretum L \\
\hline Section & Species \\
\hline \multirow[t]{4}{*}{ Hypocrateropsis Engl. \& Diels } & C. celastroides Welw. Ex Laws \\
\hline & $\begin{array}{l}\text { (i) C. celastroides ssp. celastroides } \\
\text { (ii) } \quad \text { C. celastroides ssp. orientale }\end{array}$ \\
\hline & C. imberbe Wawra \\
\hline & C. padoides Eng. \& Diels \\
\hline \multirow[t]{5}{*}{ Angustimarginata Engl. \& Diels } & C. caffrum (Eckl. \& Zeyh) Kuntze \\
\hline & C. erythrophyllum (Burch.) Sond. \\
\hline & C. kraussii Hochst \\
\hline & C. woodii Duemmer \\
\hline & C. nelsonii Duemmer \\
\hline \multirow[t]{2}{*}{ Metallicum Excell \& Stace } & C. collinum Fresen \\
\hline & $\begin{array}{l}\text { (i) C. collinum ssp. suluense } \\
\text { (ii) C. collinum ssp. taborense }\end{array}$ \\
\hline Spathulipetala Engl. \& Diels & C. zeyheri Sond. \\
\hline \multirow[t]{6}{*}{ Ciliatipetala Engl. \& Diels } & C. albopunctactum Suesseng. \\
\hline & $\begin{array}{l}\text { C. apiculatum Sond. } \\
\text { (i) C. apiculatum ssp. apiculatum }\end{array}$ \\
\hline & C. edwardsii Exell \\
\hline & C. moggii Excell \\
\hline & C. molle R. Br. \\
\hline & C. petrophilum Retief \\
\hline Breviramea Engl. \& Diels & C. hereroense Schinz \\
\hline \multirow[t]{2}{*}{ Conniventia Engl. Diels } & C. microphyllum Klotzsch \\
\hline & C. paniculatum Vent. \\
\hline \multirow[t]{3}{*}{ Poivrea (Comm. Ex DC) } & C. bracteosum (Hochst) \\
\hline & C. mossambicense (Klotzsch) \\
\hline & C. acutifolium \\
\hline
\end{tabular}

Table 2.: Terminalia species used for antioxidant screening.

\begin{tabular}{|l|}
\hline Section Abbreviate Exell \\
\hline T. prunioides M.A.Lawson \\
\hline Section Psidiodes Exell \\
\hline T. brachystemma Welw. ex Hiern \\
\hline T. sericea Burch ex DC \\
\hline Section Platycarpae Eng. Diels emend Exell \\
\hline T. gazensis Bak.f. \\
\hline T. mollis Laws \\
\hline T. sambesiaca Engl.\&Diels \\
\hline
\end{tabular}

concentration of DPPH at the end of a reaction will depend on the concentration and structure of the compound being scavenged (Naik et al., 2003).

The TLC-DPPH screening method indicated the presence of antioxidant compounds in some of the extracts tested, with $C$. woodii and $C$. hereroense showing the most prominent antioxidant activity (Figure 1). This figure was used as the representative of all Combretum species and Terminalia species tested. Visualization of the compound with antioxidant activity enables the localization and the subsequent identification of the potential active compounds. 
Masoko and Eloff Afr. J. Trad. CAM (2007) 4 (2): 231 - 239

Table 3:. Qualitative DPPH assay on TLC of the 30 plants studied

\begin{tabular}{|c|c|c|c|c|}
\hline \multirow{2}{*}{ Combretum species } & \multicolumn{4}{|c|}{ Extractants } \\
\hline & Acetone & Hexane & DCM & Methanol \\
\hline C. celastroides ssp. celastroides & ++ & - & - & ++ \\
\hline C. celastroides ssp. orientale & ++ & - & - & ++ \\
\hline C. imberbe & ++ & - & - & ++ \\
\hline C. padoides & ++ & - & - & ++ \\
\hline C. caffrum & ++ & - & - & ++ \\
\hline C. erythrophyllum & ++ & - & - & ++ \\
\hline C. kraussii & ++ & - & - & ++ \\
\hline C. woodii & +++ & & +++ & +++ \\
\hline C. collinum ssp. suluense & - & - & - & - \\
\hline C. collinum ssp. taborense & +++ & - & - & +++ \\
\hline C. zeyheri & ++ & - & - & + \\
\hline C. albopunctatum & - & - & - & + \\
\hline C. apiculatum ssp. apiculatum & ++ & - & - & ++ \\
\hline C. edwardsii & ++ & - & - & + \\
\hline C. moggi & + & - & - & ++ \\
\hline C. molle & ++ & - & - & ++ \\
\hline C. petrophilum & ++ & - & - & ++ \\
\hline C. hereroense & +++ & - & - & +++ \\
\hline C. microphyllum & + & - & - & + \\
\hline C. paniculatum & - & - & - & - \\
\hline C. bracteosum & - & - & - & - \\
\hline C. mossambicense & - & - & - & - \\
\hline C. acutifolium & ++ & - & - & ++ \\
\hline C. nelsonii & ++ & - & - & ++ \\
\hline \multicolumn{5}{|l|}{ Terminalia species } \\
\hline T. prunioides & +++ & - & - & ++ \\
\hline T. brachystemma & +++ & - & - & + \\
\hline T. sericea & +++ & - & - & +++ \\
\hline T. gazensis & +++ & - & - & +++ \\
\hline T. mollis & +++ & +++ & - & +++ \\
\hline T. sambesiaca & +++ & - & - & + \\
\hline
\end{tabular}

The degree of activity, determined qualitatively from observation of the yellow colour intensity: weak $(+)$, moderate $(++)$, strong $(+++)$ and no activity $(-)$.

The acetone and methanol extracts displayed antioxidant activity after spraying chromatograms with DPPH. Hexane and dichloromethane extracts of Terminalia species apparently did not have any antioxidant activity, but hexane and dichloromethane extracts of Combretum showed activity, although most of the active compounds were very polar. Most of the antioxidant compounds were observed in EMW. 
Masoko and Eloff Afr. J. Trad. CAM (2007) 4 (2): 231 - 239

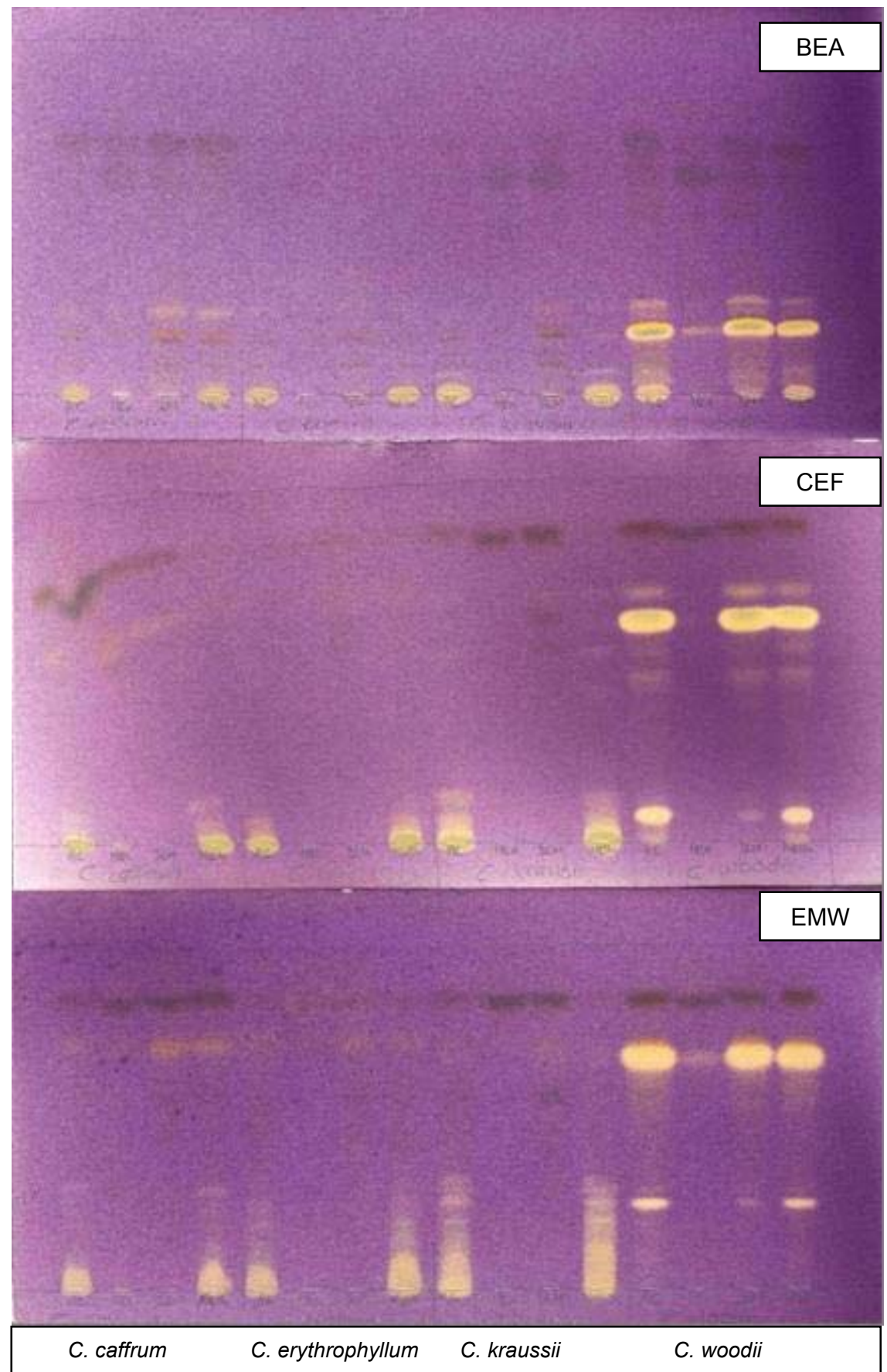

Figure 1: Chromatograms of Combretum species developed in BEA (top), CEF (centre), and EMW (bottom) solvent systems and sprayed with $0.2 \%$ DPPH in methanol. Yellow zones indicate antioxidant activity of compounds extracted with acetone (Ac), hexane (Hex), dichloromethane (D) and methanol (Met), in lanes from left to right (1-4) for each group.

Acetone, DCM and methanol extracts of $C$. woodii (Figure 1) are good candidates to isolate antioxidant active compounds from because they contained a number of compounds with a high degree of activity. The most prominent compounds were at $R_{f}$ values of 0.20 (BEA), 0.65 (CEF) and 0.73 (EMW). C. kraussii also showed antioxidant activity especially in EMW. C. collinum ssp. taborense showed antioxidant compounds in EMW from acetone and methanol extracts. The acetone extract of $C$. zeyheri showed active compounds with less activity. 
Masoko and Eloff Afr. J. Trad. CAM (2007) 4 (2): 231 - 239

Table 4. Number of antioxidant bands present in all Combretum species tested on EMW solvent systems and extractants

\begin{tabular}{|c|c|c|c|c|c|c|}
\hline \multirow{2}{*}{ Combretum species } & \multicolumn{4}{|c|}{ Extractants } & \multirow{2}{*}{ Total } & \multirow{2}{*}{ Section } \\
\hline & Acetone & Hexane & DCM & Methanol & & \\
\hline C. celastroides ssp. celastroides & 3 & & & 3 & 6 & $\mathbf{H}$ \\
\hline C. celastroides ssp. orientale & 3 & & & 1 & 4 & $\mathbf{H}$ \\
\hline C. imberbe & 1 & & & 1 & 2 & $\mathbf{H}$ \\
\hline C. padoides & 2 & & & 2 & 4 & $\mathbf{H}$ \\
\hline C. caffrum & 1 & & & 1 & 2 & A \\
\hline C. erythrophyllum & 1 & & & 2 & 3 & A \\
\hline C. kraussii & 3 & & & 3 & 6 & A \\
\hline C. woodii & 3 & & 3 & 3 & 9 & A \\
\hline C. nelsonii & 3 & & & 3 & 6 & A \\
\hline C. collinum ssp. suluense & 0 & & & 0 & 0 & $\mathbf{M}$ \\
\hline C. collinum ssp. taborense & 4 & & & 6 & 10 & $\mathbf{M}$ \\
\hline C. zeyheri & 3 & & & 1 & 4 & $\mathrm{~S}$ \\
\hline C. albopunctactum & 0 & & & 1 & 1 & $\mathbf{C}$ \\
\hline C. apiculatum ssp. apiculatum & 3 & & & 6 & 9 & $\mathbf{C}$ \\
\hline C. edwardsii & 3 & & & 1 & 4 & $\mathbf{C}$ \\
\hline C. moggi & 2 & & & 2 & 4 & C \\
\hline C. molle & 2 & & & 2 & 4 & $\mathbf{C}$ \\
\hline C. petrophilum & 3 & & & 4 & 7 & $\mathbf{C}$ \\
\hline C. hereroense & 8 & & & 8 & 16 & B \\
\hline C. microphyllum & 3 & & & 3 & 6 & Co \\
\hline C. paniculatum & 0 & & & 0 & 0 & Co \\
\hline C. bracteosum & 0 & & & 0 & 0 & $\mathbf{P}$ \\
\hline C. mossambicense & 0 & & & 0 & 0 & $\mathbf{P}$ \\
\hline C. acutifolium & 2 & & & 2 & 4 & $\mathbf{P}$ \\
\hline TOTAL & 53 & & 3 & 55 & 108 & \\
\hline
\end{tabular}

H, Hypocrateropsis; A, Angustimarginata; M, Metallicum; C, Ciliatipetala; B, Breviramea, Co, Connivetia; P, Poivrea

Table 5:. Number of antioxidant bands present in all Terminalia species tested on EMW solvent systems and extractants

\begin{tabular}{|l|c|c|c|c|c|c|}
\hline \multirow{2}{*}{ Terminalia species } & \multicolumn{3}{c|}{ Extractants } & \multirow{2}{*}{ Total } & \multirow{2}{*}{ Section } \\
\cline { 2 - 6 } & Acetone & Hexane & DCM & Methanol & & \\
\hline T. prunioides & 4 & & & 2 & 6 & A \\
\hline T. brachystemma & 4 & & & 2 & 6 & Ps \\
\hline T. sericea & 4 & & & 4 & 8 & $\mathrm{Ps}$ \\
\hline T. gazensis & 4 & & & 7 & 11 & $\mathrm{PI}$ \\
\hline T. mollis & 4 & 4 & & 6 & 14 & $\mathrm{PI}$ \\
\hline T. sambesiaca & 4 & & & 2 & 6 & $\mathrm{PI}$ \\
\hline \multicolumn{1}{|c|}{ TOTAL } & 24 & 4 & & 23 & 51 & \\
\hline
\end{tabular}

A, Abbreviatae; Ps, Psidiodes; PI, Platycarpae 
Masoko and Eloff Afr. J. Trad. CAM (2007) 4 (2): 231 - 239

The degree of activity of all the samples tested was determined qualitatively from observation of the yellow colour intensity (Table 3). Only C. woodii and T. mollis showed activity in extracts prepared with DCM and hexane, respectively. $C$. hereroense is also a good candidate to isolate antioxidant compounds from, and these active compounds were clearly visible in CEF and EMW solvent systems. C. petrophilum and C. microphyllum also had antioxidant compounds. All Terminalia species showed activity from the acetone and methanol extracts. $T$. gazensis and $T$. mollis methanol extracts showed a number of compounds in CEF and EMW systems.

The BEA and CEF solvent systems showed fewer active compounds than EMW, and active compounds were counted and recorded from TLC chromatograms developed in EMW and sprayed with DPPH for Combretum species (Table 4) and Terminalia species (Table 5). C. hereroense had the highest number of active compounds, followed by $C$. collinum ssp. taborense, which were 16 and 10, respectively. Acetone extracts of all tested Combretum species had 53 active bands in total, methanol 55, and DCM had only 3 from C. woodii (Table 4). There are differences in species in same Section. In the Metallicum section, $C$. collinum ssp. suluense did not have antioxidant activity but $C$. collinum ssp. taborense had 10 active bands. In the Connivetia section, C. microphyllum had 6 active bands and C. paniculatum had nothing, and in the Poivrea section, C. acutifolium had 4 and $C$. bracteosum and C. mossambicense had nothing.

Six tested Terminalia species had the same number of active compounds in the acetone extracts (Table 5), which was 4. Methanol extracts of the species had 23 active compounds. $T$. mollis had 4 active compounds in the hexane extract. It was the only species which have shown activity in hexane extract. Again species in the same sections had different number of active compounds. In the Psidiodes section, $T$. brachystemma had 6 active compounds and $T$. sericea had 8. In the Platycarpae section, $T$. sambesiaca had 6 active compounds and T. gazensis and T. mollis had 11 and 14 , respectively.

\section{Conclusion}

The leaves of the Combretaceae family are known for their pharmacological activity and in this paper we have shown that various solvents extracted antioxidant compounds from the leaves of plants belong to members of the Combretaceae family. Methanol and acetone extracted the highest number of antioxidant compounds based on DPPH-TLC analysis. Qualitative DPPH assay on TLC was successfully used in this study to systematically assess the total antioxidant activity of the Combretum and Terminalia species extracts. This effective and efficient method can be used for systematic screening of medicinal herbs and dietary plants for their relative antioxidant content. It is simple, fast, reliable, inexpensive, and also very adaptable to both hydrophilic and lipophilic antioxidant systems. We are currently isolating compounds with antioxidant activity from selected species.

\section{Acknowledgement}

The National Research Foundation (NRF) and University of Pretoria (UP) are acknowledged for financial assistance. The protocol for this project was approved by the research committee of the Faculty of Veterinary Sciences at the University of Pretoria.

\section{References}

1. Alexander, D. M., Bhana, N., Bhika, K. H., and Rogers, C. B. (1992). Antimicrobial testing of selected plant extracts from Combretum species. S. Afr. J. Sci, 88: 342 - 344.

2. Arnao, M. B., Cano, A., and Acosta, M. (2001). The hydrophilic and lipophilic contribution to total antioxidant activity. Food Chemistry, 73: 239-244.

3. Baba-Moussa, F., Akpagana, K. and Bouchet, P. (1998). Antifungal activities of seven West African Combretaceae used in traditional medicine. J. Ethnopharmacol, 66: 335-338.

4. Bouchet, N., Levesque, J., Blond, A., Bodo, B., and. Pousset, J.L. (1996). 1,3-di-O-galloylquinic acid from Guiera senegalensis, Phytochemistry, 42: 189-190.

5. Bouchet, N., Barrier, L. and Fauconneau, B. (1998). Radical scavenging activity and antioxidant properties of tannins from Guiera senegalensis (Combretaceae), Phytother. Res., 12: 159-162.

6. Cai, Y.Z., Sun, M., and Corke, H. (2003). Antioxidant activity of betalains from plants of the Amaranthaceae. J. Agricult. Food Chem., 51(8): 2288-2294. 
Masoko and Eloff Afr. J. Trad. CAM (2007) 4 (2): 231 - 239

7. Carr, J. D. (1988). Combretaceae in southern Africa. Tree Society of southern Africa, Johannesburg.

8. Cheng, H.Y., Lin, T.C., Yu, K.H., Yang C.M., and Lin, C.C. (2003). Antioxidant and free radical scavenging activities of Terminalia chebula. Biol. Pharmaceut. Bull. 26: 1331-1335.

9. Deby, C., and Margotteaux G. (1970). Relationship between essential fatty acids and tissue antioxidant levels in mice. C R Seances Soc Biol Fil., 165: 2675-2681.

10.Eloff, J.N. (1998). Conservation of Medicinal Plants: Selecting Medicinal Plants for research and gene banking. Monographs in Systematic Botany from the Missouri Garden 71, 209-222 In : Conservation of plants Genes III: Conservation and utilisation of African plants. Robert P. Adams and Janice E. Adams, eds., Missouri Botanical Garden Press, St.Louis, USA.

11.Eloff, J. N., (1999). The antibacterial activity of 27 Southern African members of the Combretaceae, S. Afri. J. Sci. 95: 148-152.

12. Finkel, T., and Holbrook, N.J., (2000). Oxidants, oxidative stress and biology of ageing, Nature, 408: 239-247.

13. Fyhrquist, P., Mwasumbi, L., Haeggstrom, C. -A., Vuorela, H., Hiltunen, R. and Vuorela, P., (2002). Ethnobotanical and antimicrobial investigation of some species of Terminalia and Combretum (Combretaceae) growing in Tanzania. J Ethnopharmacol., 79: 169-177.

14.Gupta, R., Singhal, S., Goyle, A., and Sharma, V.N. (2001). Antioxidant and hypocholesterolaemic effects of Terminalia arjuna tree-bark powder: a randomised placebocontrolled trial, J. Assoc. Physicians India, 49: 231-235.

15. Halliwell, B., and Gutteridge, J.M.C. (1999). The definition and measurement of antioxidant in biological systems, Free Radic. Biol. and Med., 18 (1), 125-126.

16. Heinrich, M., and Gibbons, S. (2001). Ethnopharmacology in drug discovery: an analysis of its role and potential contributions, J Pharm. Pharmacol., 53: 425-432.

17. Imaida, K., Fukushima, T., Shivali, T., Ohtani, M., Nakanish, K., and Ito, N. (1983). Promotong activities of butylated hydroxy anisole and butylated hydroxy toluene on 2 stage urinary bladder cacinogenesis and inhibition of $y$-glutamyl transpaptidase-positive foci development in the liver of rats, Carcinogenesis, 4: 885-889.

18. Kotze, M., and Eloff, J. N., (2002). Extraction of antibacterial compounds from Combretum microphyllum (Combretaceae). SAJB, 68: 62-67.

19.Li, Y., and Trush, M.A. (1994). Reactive oxygen dependent DNA damage resulting from the oxidation of phenolic compounds by a copper redox cycle, Cancer Res., 54: 1895s-1898s.

20.Mabogo, D.E.N., (1990). The ethnobotany of the Vhavenda. M.Sc. thesis, University of Pretoria.

21. Martini, N. and Eloff, J.N (1998) The preliminary isolation of several antibacterial compounds from Combretum erythrophyllum (Combretaceae). J Ethnopharmacol., 62: 255-263.

22. Martini, N, Katerere, D.R.P., and Eloff, J.N., (2004). Biological activity of five antibacterial flavonoids isolated from Combretum erythrophyllum (Combretaceae). J Ethnopharmacol., 93: 207-212.

23. Masoko, P., Picard, J., and Eloff, J.N. (2005). Antifungal activities of six South African Terminalia species (Combretaceae), J Ethnopharmacol., 99: 301-308.

24. Masoko, P., Picard, J., and Eloff, J.N. (2006). The antifungal activity of twenty-four southern African Combretum species (Combretaceae). SAJB (In Press).

25. Naik, G. H., Priyadarsini, K. I., Satav, J. G., Banavalikar, M. M., Sohoni, D. P., Biyani, M. K and Mohan, H., (2003). Comparative antioxidant activity of individual herbal components used in Ayurvedic medicine. Phytochemistry, 63(1): 97-104.

26. Nose, K., (2000). Role of reactive oxygen species in regulation of physiological functions, Biol. Pharmaceut. Bull. 22: 897-903.

27. Owen R.W., A. Giacosa, W.E. Hull, R. Haubner, B. Spiegelhalder and H. Bartsch, (2000). The antioxidant/anticancer potential of phenolic compounds isolated from olive oil. Eur. J. Cancer, 36 (10):1235-1247.

28. Sala, A., Recio, M.D., Giner, R.M., Manez, S., Tournier, H., Schinella G., and Rios, J.L. (2002). Antiinflammatory and antioxidant properties of Helichrysum italicum. J. Pharm. and Pharmacol., 54 (3): 365371.

29. Silva O., Duarte A., Cabrita J., Pimentel M., Diniz A. and Gomes E (1996) Antimicrobial activity of GuineaBissau traditional remedies. J Ethnopharmacol., 50: 55-59.

30. Zheng, W., and Wang, S.Y. (2001). Antioxidant activity and phenolic compounds in selected herbs. J. Agricul. Food Chem., 49(11): 5165-5170. 